\title{
Dimensi Pengetahuan FKPM (Faktual, Konseptual, Prosedural, dan Metakognitif) Mahasiswa IPA pada Pembelajaran Mekanika
}

\author{
Faninda Novika Pertiwi \\ IAIN Ponorogo \\ fanindanovik@yahoo.com
}

\begin{abstract}
Abstrak
Mekanika merupakan cabang ilmu fisika tertua yang menjadi dasar cabang ilmu lainnya, sehingga mahasiswa IPA wajib mempelajari dan memahaminya. Selama ini, jarang dilakukan penilaian terkait dimensi pengetahuan. Padahal hal ini sangatlah penting untuk mencapai keberhasilan pembelajaran. Dimensi pengetahuan yang dimaksud di sini yaitu tingkatan pengetahuan faktual, konseptual, prosedural, dan metakognitif. Tujuan penelitian ini yaitu untuk mengetahui dimensi pengetahuan mahasiswa pada mata kuliah mekanika dasar. Jenis penelitian ini adalah kualitatif. Data yang didapatkan pada penelitian ini meliputi tingkatan pengetahuan dan pemahaman konsep mahasiswa. Teknik pengumpulan data menggunakan tes essay dan wawancara. Sumber datanya adalah mahasiswa yang sedang menempuh mata kuliah mekanika dasar. Hasil penelitian menunjukkan bahwa sebanyak 9\% mahasiswa memiliki tingkatan pengetahuan faktual, 31\% konseptual, $48 \%$ prosedural, dan 12\% Metakognitif. Rata-rata nilai pemahaman konsep mahasiswa 79. Terdapat hubungan positif antara dimensi pengetahuan dengan pemahaman konsep mahasiswa. Semakin tinggi dimensi pengetahuan yang dimiliki mahasiswa maka pemahaman konsepnya juga semakin bagus.
\end{abstract}

Kata Kunci: Dimensi Pengetahuan, FKPM, Pemahaman Konsep, Mekanika

\begin{abstract}
Mechanics is the oldest branch of physics on which other branches of science are based, so science students are obliged to study and understand it. So far, it is seldom done an assessment related to the dimension of knowledge. Even though this is very important to achieve learning success. The dimension of knowledge referred to here is the level of factual knowledge, conceptual, procedural and metacognitive. The purpose of this study is to determine the dimensions of student knowledge in basic mechanics courses. This type of research is qualitative. The data obtained in this study included the level of knowledge and understanding of students' concepts. Data collection techniques used essay tests and interviews. The data source is students who are currently taking basic mechanics courses. The results showed that as many as $9 \%$ of students had a level of factual knowledge, 31\% conceptual, $48 \%$ procedural, and $12 \%$ metacognitive. The average value of students 'conceptual understanding is 79. There is a positive relationship between the dimensions of knowledge and students' conceptual understanding. The higher the dimension of knowledge a student has, the better the conceptual understanding is.
\end{abstract}

Kata Kunci: Knowledge Dimensions, FKPM, Concept Understanding, Mechanics

\section{A. PENDAHULUAN}

Ilmu pengetahuan Alam merupakan ilmu yang mempelajari alam semesta beserta isi dan kandungannya, termasuk di dalamnya terkait makhluk hidup maupun 
makhluk tak hidup. IPA berasal dari kata sains yang bermakna alam. Menurut Suyoso, IPA merupakan pengetahuan hasil kegiatan manusia yang bersifat aktif dan dinamis tiada henti-hentinya serta diperoleh melalui metode tertentu yaitu teratur, sistematis, berobjek, bermetode, dan berlaku secara universal. ${ }^{1}$ Sedangkan menurut Abdullah, IPA merupakan pengetahuan teoritis yang diperoleh atau disusun dengan cara yang khas atau khusus, yaitu dengan melakukan observasi, eksperimentasi, penyimpulan, penyusunan teori, eksperimentasi, observasi dan seperti itu seterusnya kait mengkaitkan antara cara yang satu dengan cara yang lain. ${ }^{2}$ Berdasarkan hal tersebut maka dapat dijelaskan bahwa IPA merupakan wujud dari hasil kegiatan manusia yang didapatkan dari langkah-langkah ilmiah yang berupa metode ilmiah yang didapatkan dari hasil eksperimen atau observasi. Pada pembelajaran IPA, segala hal terkait alam dan segala persoalannya dipelajari dengan ilmiah. IPA terdiri dari tiga aspek yang saling melengkapi, yaitu fisika, biologi, dan kimia. Pada aspek fisika mempelajari bagian IPA terkait benda-benda tak hidup. Aspek biologi mempelajari IPA terkait benda-benda hidup serta lingkungannya. Kemudian aspek kimia mempelajari IPA dari segi gejalagejala kimia yang ada pada benda hidup maupun tak hidup. Oleh karena itu mempelajari IPA berarti manusia telah mempelajari aspek fisika biologi kimia secara bergantian maupun bersamaan.

Di IAIN Ponorogo IPA merupakan jurusan baru yang pertama dibuka pada tahun 2016. Angkatan pertama jurusan tadris IPA ini adalah 1 kelas yang berjumlah 36 mahasiswa. Meskipun jurusan baru namun peminat dan semangat mahasiswa nya cukup baik. Pada jurusan IPA terdapat beberapa mata kuliah terkait keahlian, seperti fisika dasar, biologi dasar, dan kimia dasar. Mata kuliah dasar ini diberikan untuk menunjang mata kuliah-mata kuliah keahlian yang selanjutnya. Seperti mekanika dasar, termodinamika, gelombang optik, bioteknologi dsb. Oleh karena itu mahasiswa tadris IPA wajib mempelajari dan memahami mata kuliah-mata kuliah yang diberikan mulai dari awal perkuliahan. Pada aspek fisika, cabang ilmu tertua dari fisika adalah Mekanika. Mekanika merupakan ilmu fisika yang mempelajari segala sesuatu tentang gerak. Mekanika merupakan ilmu Fisika yang mempelajari keadaan status benda, baik dalam keadaan diam atau bergerak akibat pengaruh gaya-gaya yang bekerja. Mekanika sangat penting perannya dalam sistem analisis kerekayasaan, dan seringkali orang menyebut bahwa awal dari rekayasa adalah mekanika. Ilmu mekanika tergolong ilmu fisika yang paling tua dibandingkan ilmu-ilmu fisika yang lain. Mekanika sendiri terdiri dari kinematika dan dinamika. Kinematika mempelajari segala sesuatu tentang gerak tanpa disertai penyebabnya, sedangkan dinamika mempelajari segala sesuatu tentang gerak dengan disertai penyebabnya. Penyebab gerak disini adalah gaya. Berdasarkan hal di atas, maka mekanika merupakan ilmu yang mendasari materi-materi fisika selanjutnya. Oleh karena itu sebagai calon pendidik IPA, maka mahasiswa IPA wajib memahami dan

1Eneng Khoerunisa, "Meningkatkan Hasil Belajar Siswa Pada Pelajaran IPA Materi Siklus Air Dengan Menerapkan Metode Pembelajaran Eksperimen,” 2013.

${ }^{2}$ Khoerunisa. 
lulus mata kuliah fisika dasar maupun mekanika dasar. Mahasiswa wajib menguasai konsep terkait mekanika tersebut.

Selama ini, ketika menentukan nilai mahasiswa terkait mata kuliah mekanika dasar, fisika dasar maupun mata kuliah yang lain, sebagian besar melalui tes tulis, harian di kelas maupun dengan tugas-tugas. Belum pernah dilakukan suatu tes untuk mengetahui seberapa tingkat pengetahuan mahasiswa tersebut terkait materi. Dimensi pengetahuan di sini menyangkut pengetahuan faktual, konseptual, prosedural, dan metakognitif. Dimensi pengetahuan ini penting karena jika seorang pendidik mampu mengenali, memahami, serta memilah dimensi pengetahuan tersebut maka pendidik akan mudah mendeskripsikan materi pelajaran sesuai kompetensi dasar yang dipelajari. Serta memudahkan pendidik dalam menjelaskan materi sehingga tujuan pembelajaran tercapai. Pengetahuan faktual yaitu tingkatan pengetahuan yang pertama. Pengetahuan faktual, mencakup pengetahuan tentang terminologi yaitu pengertian atau definisi, dan pengetahuan tentang detail-detail dan elemen-elemen yang spesifik yaitu pengetahuan tentang peristiwa, lokasi, tanggal, orang, sumber informasi dan lainnya yang berdasar pada fakta. ${ }^{3}$ Contoh pengetahuan faktual misalnya mobil bergerak. Mahasiswa tersebut mengetahui mobil tersebut faktanya bergerak bukan diam. Benda bergerak dan diam ini berbeda acuan, perlakuan dsb secara fisika. Dimensi pengetahuan selanjutnya adalah konseptual. Anderson dan Krathwohl mengemukakan bahwa pengetahuan konseptual merupakan bentuk-bentuk pengetahuan yang lebih kompleks dan terorganisasi. ${ }^{4}$ Contoh pengetahuan konseptual adalah bahwa benda bergerak atau diam dalam fisika termasuk konsep gerak atau mekanika. Benda bergerak maupun diam dapat dianalisis secara kinematika maupun dinamika. Dimensi pengetahuan selanjutnya adalah pengetahuan prosedural. Pengetahuan prosedural ini merupakan pengetahuan tentang keterampilan khusus yang diperlukan untuk bekerja dalam suatu bidang ilmu atau tentang algoritme yang harus ditempuh untuk menyelesaikan suatu permasalahan. ${ }^{5}$ Pengetahuan prosedural dapat diungkapkan sebagai suatu rangkaian langkah-langkah, yang secara kolektif dikenal sebagai prosedur. Contoh pengetahuan prosedural yaitu jika suatu benda bergerak maka dapat dianalisis secara kinematika yaitu meliputi perpindahan, jarak, kecepatan, kelajuan, percepatan, dan perlajuannya. Namun dapat pula dianalisis secara dinamika yaitu gaya apa yang menyebabkan benda bergerak, berapa gaya yang menyebabkan benda bergerak maupun berhenti, kapan gaya diberikan untuk menghentikan suatu benda dsb. Dimensi pengetahuan terakhir yaitu pengetahuan metakognitif. Dimensi pengetahuan metakognitif ini adalah pengetahuan metakognitif, mencakup pengetahuan strategis, yaitu strategi belajar dan berfikir untuk memecahkan masalah. Pengetahuan metakognitif pada penelitian ini dikaitkan dengan kemampuan analisis terhadap penyelesaian soal atau permasalahan pada suatu pokok

${ }^{3}$ Khoerunisa.

${ }^{4}$ L.W. Anderson and D.R. Krathwohl, Pembelajaran, Pengajaran Dan Asesmen (Revisi Taksonomi Pendidikan Bloom) (Yogyakarta: Pustaka Pelajar, 2009).

5“Konstruktivisme Dan Pembelajaran Sains," 200713 (n.d.): 91-105. 
bahasan tertentu. ${ }^{6}$ Pengetahuan metakognitif merupakan dimensi pengetahuan yang paling kompleks. Contohnya yaitu benda bergerak tentu memiliki jarak dan perpindahan, tetapi antara jarak dan perpindahan ini merupakan dua besaran fisika yang berbeda. Sehingga dalam menentukan jarak berbeda dengan menentukan perpindahan suatu benda. Begitu pula kecepatan dan kelajuan. Keduanya adalah hal yang berbeda meskipun terjadi dalam waktu yang bersamaan. Selain itu ketika suatu benda bergerak maka tidak hanya mekanika yang mempelajarinya namun dapat juga dikaitkan dengan usaha dan energi, dsb.

Penelitian tentang dimensi pengetahuan masih jarang dilakukan, beberapa penelitian terdahulu seperti penelitian yang dilakukan oleh Anggun yaitu tentang hubungan tingkat pengetahuan dengan sikap masyarakat didapatkan hasil terdapat 3 responden (3.1\%) yang memiliki tingkat pengetahuan kurang, sebanyak 36 responden (36.7\%) yang memiliki tingkat pengetahuan cukup dan sebanyak 59 responden $(60,2 \%)$ yang memiliki tingkat pengetahuan baik tentang skistosomiasis di Kecamatan Lindu Kabupaten Sigi, dan terdapat 6 responden (6,1\%) yang memiliki sikap cukup dan 92 responden (93.9\%) memiliki sikap yang baik tentang skistosomiasis di Kecamatan Lindu Kabupaten Sigi. Hasil penelitian yang dilakukan hanya sebatas kurang, cukup, dan baik. Tingkatan pengetahuan yang diteliti tidak sampai mencakup factual, konseptual, procedural, dan metakognitif. Selanjutnya, penelitian yang dilakukan Devi mendapatkan kesimpulan yaitu tingkatan pengetahuan dapat mempengaruhi perilaku seseorang. Pengetahuan diperoleh dari informasi yang diterima sepanjang hidupnya. Sikap memberikan gambaran terhadap tindakan yang akan dilakukan sehingga dengan demikian sikap dapat mempengaruhi perilaku seseorang di dalam kehidupannya.

Berdasarkan hal di atas, maka penelitian yang dilakukan ini bertujuan untuk mengetahui dimensi pengetahuan mahasiswa pada mata kuliah mekanika dasar kemudian menggali dimensi pengetahuan tersebut agar semakin baik. Hal ini karena dimensi pengetahuan bermanfaat untuk prestasi akademiknya. Oleh karena itu sebagai mahasiswa IPA sudah semestinya memiliki dimensi pengetahuan yang tinggi setidaknya bukan hanya faktual. Sangat diharapkan jika mahasiswa memiliki tingkatan pengetahuan metekognitif. Namun, selama ini belum pernah dilakukan penelitian terkait dimensi pengetahuan yang dimiliki mahasiswa. Oleh karena itu, peneliti tertarik melakukan penelitian dengan judul Dimensi Pengetahuan FKPM (Faktual, Konseptual, Prosedural, dan Metakognitif) Mahasiswa IPA dalam Pembelajaran Mekanika.

\section{B. METODE PENELITIAN}

Metode penelitian yang dilakukan adalah metode kualitatif. Jenis penelitian yang dilakukan yaitu studi kasus yang berkaitan dengan tingkatan pengetahuan mahasiswa khususnya pada pembelajaran mekanika dasar. Penelitian yang dilakukan bertujuan

${ }^{6}$ Nisa dkk Sholihat, "Kompetensi Pengetahuan 'Metode Pembelajaran' Sebagai Kesiapan Program Pengalaman Lapangan (PPL) Mahasiswa Prodi Pendidikan Tata Boga," Media Pendidikan Gizi Dan Kuliner Vol.7, No.1 (April 2018). 
untuk mendeskripsikan dimensi pengetahuan dan pemahaman konsep mahasiswa pada materi mekanika. Serta mendeskripsikan hubungan antara dimensi pengetahuan dan pemahaman konsep mahasiswa. Pendekatan penelitian yang dilakukan adalah melalui pendekatan proses yaitu memberikan kesempatan sebesar-besarnya kepada peneliti untuk menyampaikan segala kejadian yang ditemukan selama pengambilan data.

Data yang diperoleh adalah data dimensi pengetahuan yang dimiliki mahasiswa, kemampuan pemahaman konsep mekanika, serta hubungan antara dimensi pengetahuan dengan pemahaman konsep mahasiswa. Sumber data pada penelitian ini adalah mahasiswa IPA yang berjumlah 82 orang yang tersebar di empat kelas.

Teknik pengumpulan data pada penelitian ini yaitu dengan tes berbentuk essay serta metode wawacara. Tes essay digunakan untuk menggali data tentang tingkatan pengetahuan yang dimiliki mahasiswa serta sekaligus nilai dari hasil tes dapat digunakan sebagai data kemampuan pemahaman konsep mahasiswa. Wawancara yang dilakukan bertujuan untuk menggali lebih mendalam tentang kemampuan pemahaman konsep mahasiswa. Instrumen penelitian yang digunakan pada penelitian ini yaitu soal tes dan pedoman wawancara. Pedoman wawancara berisi butir-butir pertanyaan yang berhubungan sejauh mana mampu memahami materi mekanika kemudian mudah atau sulit mempelajari mekanika dsb.

Fokus dalam penelitian kualitatif merupakan domain tunggal atau beberapa domain yang terkait dari situasi sosial yang akan diteliti. ${ }^{7}$ Fokus dalam penelitian ini adalah menganalisis secara deskriptif terkait dimensi pengetahuan FKPM (faktual konseptual prosedural dan metakognitif), pemahaman konsep fisika mahasiswa terkait mekanika dasar serta terkait hubungan antara dimensi pengetahuan dan pemahaman konsep mahasiswa. Analisis data yang digunakan dalam penelitian ini dengan menggunakan metode kualitatif. Analisis data kualitatif berlangsung selama proses pengumpulan data dari pada setelah selesai pengumpulan data. Jadi, pada penelitian kualitatif analisis lebih difokuskan sebelum memasuki lapangan dan selama di lapangan. ${ }^{8}$

Pada penelitian ini, data yang diperoleh dari beberapa metode pengumpulan data, seperti: observasi, wawancara, dan dokumentasi, dianalisis secara deskriptif. Data kualitatif yang diperoleh ini dideskripsikan dan proses pengambilan keputusan diambil dengan pembandingan masing-masing komponen dan indikator berdasarkan kriteria yang telah ditentukan.

Analisis data yang dilakukan pada penelitian ini yaitu berdasarkan menganalisis hasil jawaban dari tes essay, observasi, serta dokumentasi yang ada. Berdasarkan jawaban mahasiswa setelah mengerjakan tes essay yang diberikan maka dimensi pengetahuannya dikategorikan ke dalam tingkatan pengetahuan faktual, konseptual, prosedural atau tingkat metakognitif. Kemudian hasil jawaban tes ini juga dapat

\footnotetext{
${ }^{7}$ Sugiyono, Metode Penelitian Kuantitatif Kualitatif Dan R\&D (Bandung: Alfabeta, 2011), 207-209.

${ }^{8}$ Sugiyono, 244-45.
} 
dijadikan dasar menentukan sejauh mana tingkat pemahaman konsep mahasiswa pada mata kuliah mekanika dasar.

Hasil dokumentasi dan observasi juga dianalisis dengan teknik triangulasi, dibandingkan hasilnya untuk mendapatkan data yang valid. Namun analisis data tersebut juga memperhatikan keadaan yang ditemui di lapangan berdasarkan observasi yang dilakukan. Data yang diperoleh di lapangan, selanjutnya dianalisis dengan model Milles dan Huberman. Miles dan Huberman mengemukakan bahwa aktivitas dalam analisis data kualitatif dilakukan secara interaktif dan berlangsung secara terus menerus sampai data tersebut jenuh. ${ }^{9}$ Analisis data lapangan tersebut meliputi:

1. Reduksi data

Apabila data yang diperoleh dari lapangan jumlahnya semakin banyak, kompleks dan rumit, maka perlu dilakukan analisis data melalui reduksi data. Mereduksi data berarti merangkum, memilih hal-hal yang pokok, memfokuskan pada hal-hal yang penting, dicari tema dan polanya. ${ }^{10}$

Reduksi data bertujuan untuk memilih dan menyederhanakan data agar tidak terjadi penumpukan data atau informasi yang sama. Setelah direduksi data akan memberi gambaran yang lebih tajam tentang hasil pengamatan. Kegiatan ini dapat memudahkan peneliti untuk melakukan pengumpulan data selanjutnya.

2. Penyajian data

Setelah data direduksi, maka langkah selanjutnya adalah menyajikan data. Dalam penelitian kualitatif, penyajian data bisa dilakukan dalam bentuk uraian singkat, bagan, hubungan antar kategori, flowchart dan sejenisnya. Hal yang paling sering digunakan dalam penelitian kualitatif untuk menyajikan data adalah dengan teks yang bersifat naratif. ${ }^{11}$

Penyajian data dapat diartikan sebagai usaha untuk menyusun sekumpulan informasi yang telah diperoleh di lapangan dengan menyajikan data tersebut secara jelas dan sistematis sehingga akan mempermudah peneliti dalam mengambil kesimpulan. Data yang telah direduksi, kemudian diklasifikasikan dan disajikan.

3. Penarikan kesimpulan/verifikasi

Dari data hasil penelitian yang telah dilakukan selanjutnya data tersebut ditarik kesimpulan. Penarikan kesimpulan didasarkan atas sajian data dengan tujuan untuk memperoleh kesimpulan tentang tata kelola, peran serta efektivitas laboratorium IPA SMP di Ponorogo. Kesimpulan dalam penelitian kualitatif merupakan hal baru yang sebelumnya belum pernah ada yang dapat berupa deskripsi atau gambaran suatu obyek yang sebelumnya masih remang-remang atau belum jelas sehingga setelah diteliti menjadi jelas, dapat berupa hubungan kausal atau interaktif, hipotesis atau teori.

\footnotetext{
${ }^{9}$ Sugiyono, 337.

10 Sugiyono, 247.

11 Sugiyono, 249.
} 
Analisis data yang dilakukan pada penelitian ini yaitu berdasarkan menganalisis hasil jawaban dari tes essay, observasi, serta dokumentasi yang ada. Berdasarkan jawaban mahasiswa setelah mengerjakan tes essay yang diberikan maka dimensi pengetahuannya dikategorikan ke dalam tingkatan pengetahuan faktual, konseptual, prosedural atau tingkat metakognitif. Kemudian hasil jawaban tes ini juga dapat dijadikan dasar menentukan sejauh mana tingkat pemahaman konsep mahasiswa pada mata kuliah mekanika dasar.

\section{HASIL DAN PEMBAHASAN}

\section{Dimensi Pengetahuan}

Berdasarkan hasil tes yang telah didapatkan maka jawaban-jawaban yang telah dituliskan peserta didik diamati dan dianalisis sejauh mana tingkat pengetahuannya. Sebanyak 9\% dari mahasiswa memiliki tingkat pengetahuan faktual. Secara teori, pengetahuan faktual mencakup pengetahuan tentang terminologi yaitu pengertian atau definisi, dan pengetahuan tentang detail-detail dan elemen-elemen yang spesifik yaitu pengetahuan tentang peristiwa, lokasi, tanggal, orang, sumber informasi dan lainnya yang berdasar pada fakta. ${ }^{12}$ Pada hasil penelitian yang didapat, pengetahuan faktual dapat ditinjau berdasarkan jawaban siswa terkait pertanyaan yang diajukan yaitu hubungan Hukum II Newton dengan transfer dan transformasi energi. Jawaban mahasiswa yang tingkatan pengetahuannya masuk ke kategori faktual yaitu hanya menuliskan bahwa Hukum II Newton itu membahas tentang benda bergerak sehingga membahas tentang percepatan. Ada juga yang hanya menuliskan bahwa rumus hukum II Newton yaitu $\sum F=m . a$. Mahasiswa yang memiliki tingkat pengetahuan faktual memang hanya sebatas tahu tentang suatu fakta tanpa mau atau dapat menghubungkan fakta-fakta yang ada tersebut. Meskipun pertanyaannya jelas diminta untuk mencari keterkaitan antara Hukum II Newton dengan transfer dan transformasi energi. Hal ini juga sesuai dengan teori bahwa menurut Sukmadinata, contoh pengetahuan faktual berupa istilah ilmu, lambang bilangan, simbol matematika, simbol musik, simbol kimia, dll. ${ }^{13}$ Pada kasus ini mahasiswa hanya sebatas mengetahui rumus atau persamaan Hukum II Newton atau sebatas mengetahui tentang konsep Hukum II Newton maka dapat disebut tingkatan pengetahuannya adalah masih tingkat faktual.

Selanjutnya, berdasarkan hasil jawaban mahasiswa ada sebanyak 31\% yang memiliki tingkat pengetahuan konseptual. Secara teori pengetahuan konseptual meliputi teori yang mempresentasikan pengetahuan manusia tentang bagaimana suatu materi kajian disusun atau distrukturkan, bagaimana bagian-bagian informasi saling

\footnotetext{
${ }^{12}$ Sholihat, "Kompetensi Pengetahuan 'Metode Pembelajaran' Sebagai Kesiapan Program Pengalaman Lapangan (PPL) Mahasiswa Prodi Pendidikan Tata Boga."

${ }^{13}$ Nana Syaodih Sukmadinata, Landasan Psikologi Proses Pendidikan (Bandung: Remaja Rosdakarya, 2004).
} 
terkait secara sistematis, dan bagaimana bagian-bagian ini berfungsi bersama. ${ }^{14}$ Pengetahuan konseptual dalam penelitian ini dikaitkan dengan pengetahuan tentang prinsip, dimana mahasiswa dapat memilih prinsip metode pembelajaran serta membedakan prinsip metode yang satu dengan lainnya ${ }^{15}$. Menurut Anderson dan Krathwohl, mahasiswa dikatakan memiliki tingkatan pengetahuan konseptual yaitu apabila mahasiswa mampu mengemukakan tentang bentuk-bentuk pengetahuan yang lebih kompleks dan terorganisasi. ${ }^{16}$ Dalam hal ini dikatakan mahasiswa memiliki tingkatan pengetahuan konseptual yaitu apabila mahasiswa dapat menuliskan konsep tentang Hukum II Newton jadi tidak hanya sebatas rumus serta pengertiannya. Pengetahuan konseptual, merupakan pengetahuan yang lebih kompleks berbentuk klasifikasi, kategori, prinsip dan generalisasi.

Sebanyak 31\% mahasiswa telah mencapai tingkatan pengetahuan konseptual ini. Hal ini karena pada semester 1 mahasiswa telah menempuh mata kuliah fisika dasar 1 dimana di dalamnya telah dibahas tentang materi Hukum Newton. Beberapa contoh jawaban mahasiswa yang memiliki tingkatan pengetahuan konseptual yaitu mahasiswa tersebut mengetahui bahwa pada Hukum II Newton ada hubungan antara massa suatu benda gaya serta percepatannya. Semakin besar massa suatu benda maka benda tersebut akan memiliki percepatan yang kecil. Percepatan suatu benda berbanding terbalik dengan massa suatu benda. Kemudian mahasiswa juga telah mengetahui bahwa resultan gaya yang bekerja pada benda yang menyebabkan adanya perubahan kecepatan yang dalam hal ini disebut percepatan. Jika resultan gaya besar maka percepatan benda juga besar. Sehingga pada Hukum II Newton itu membahas tentang percepatan suatu benda sebanding dengan resultan gaya yang bekerja pada benda serta berbanding terbalik dengan massanya. Mahasiswa juga mampu menuliskan bahwa adanya suatu percepatan maka jelas disitu ada suatu energi. Kemudian ada resultan gaya yang bekerja maka hal ini jelas ada energi yang berpengaruh. Sehingga jelas bahwa ada kaitannya antara Hukum II Newton dengan energi. Tetapi dalam hal ini mahasiswa belum mampu menjelaskan kaitannya dengan transfer serta transformasi energi.

Selanjutnya mahasiswa yang memiliki tingkat pengetahuan prosedural sebanyak 48\%. Pengetahuan prosedural ini merupakan pengetahuan tentang keterampilan khusus yang diperlukan untuk bekerja dalam suatu bidang ilmu atau tentang algoritme yang harus ditempuh untuk menyelesaikan suatu permasalahan ${ }^{17}$. Menurut Suwarto, mahasiswa yang memiliki tingkatan pengetahuan prosedural ini maka mahasiswa mampu mengungkapkan suatu rangkaian langkah-langkah, yang

${ }^{14}$ Naning Sutriningsih, "The Profile Of Teacher Questions On Mathematics Lessons in IX Class Students With Visual Impairment SMPLB YKAB Surakarta. Proceeding of International Conference On Research, Implementation And Education Of Mathematics And Sciences 2014," Yogyakarta State University, 2014.

${ }^{15}$ Sholihat, "Kompetensi Pengetahuan 'Metode Pembelajaran' Sebagai Kesiapan Program Pengalaman Lapangan (PPL) Mahasiswa Prodi Pendidikan Tata Boga."

${ }^{16}$ Anderson and Krathwohl, Pembelajaran, Pengajaran Dan Asesmen (Revisi Taksonomi Pendidikan Bloom).

${ }^{17}$ Nengsih Juanengsih, "Juanengsih, Nengsih, Dkk. 2017. Pengaruh Model Pembelajaran Berbasis Proyek Terhadap Pengetahuan Prosedural Siswa Pada Konsep Eubacteria.," BIOEDUKASI Volume 10, Nomor 2 Halaman 23 - 28. 2017 (2017). 
secara kolektif dikenal sebagai prosedur. Meskipun proses tersebut merupakan suatu hal yang penting namun hasil akhirnya secara umum juga merupakan bagian dari jenis pengetahuan. ${ }^{18}$

Mahasiswa yang mampu menguraikan persamaan Hukum II Newton dan halhal terkait transfer serta transformasi energi dengan menjabarkan tahap demi tahapnya maka mahasiswa ini memiliki tingkat pengetahuan prosedural. Beberapa contoh jawaban yang disampaikan mahasiswa terkait pertanyaan ini yaitu mahasiswa menuliskan pernyataan Hukum II Newton kemudian setelah menuliskan pernyataannya maka mahasiswa menurunkannya dalam bentuk persamaan. Kemudian mahasiswa menjelaskan tentang transfer dan transformasi energi serta mengemukakan perbedaanya. Transfer energi merupakan salah satu sifat energi yang mampu berpindah, contoh transfer energi itu yaitu jika merebus air maka ada transfer energi dari api ke air. Transformasi energi yaitu membahas tentang sifat energi yang dapat berubah bentuk, contoh transformasi energi yaitu ketika proses merebus air tersebut energi panas berubah menjadi energi uap. Mahasiswa yang memiliki tingkat pengetahuan prosedural mampu menguraikan tahapan demi tahapan dari suatu fakta atau konsep. Namun terkadang kemampuan menjabarkan tahapan demi tahapan ini belum diimbangi dengan kemampuan berpikir tentang kaitan atau hubungan kedua konsep yang sedang ditanyakan. Namun mahasiswa yang memiliki tingkatan pengetahuan prosedural ini sudah cukup baik kemampuan berpikirnya. Menurut Suwarto, melalui kemampuan berpikirnya dengan tingkat pengetahuan prosedural maka para mahasiswa memperoleh makna ketika mereka mengkaitkan dengan situasisituasi dan masalah-masalah yang konkret. ${ }^{19}$ Pengetahuan prosedural ini jika diaplikasikan di laboratorium maka mahasiswa dikatakan memiliki tingkatan prosedural jika mahasiswa tersebut paham dan mengetahui langkah-langkah dalam melakukan percobaan mulai dari awal merangkai alat hingga mendapatkan data. Jika mahasiswa memahami tahapannya dengan benar maka mahasiswa ini disebut memiliki tingkatan pengetahuan prosedural.

Tingkatan pengetahuan yang terakhir yaitu tingkatan pengetahuan metakoginitif. Pengetahuan metakognitif, mencakup pengetahuan strategis, yaitu strategi belajar dan berfikir untuk memecahkan masalah. Pengetahuan metakognitif pada penelitian ini dikaitkan dengan kemampuan analisis terhadap penyelesaian soal atau suatu permasalahan terkait materi pada suatu pokok bahasan tertentu. ${ }^{20}$ Pengetahuan metakognitif pada penelitian ini dikaitkan dengan kemampuan analisis terhadap penyelesaian soal atau suatu permasalahan terkait materi pada suatu pokok

\footnotetext{
${ }^{18}$ Juanengsih.

${ }^{19}$ Suwarto, "Dimensi Pengetahuan Dan Dimensi Proses Kognitif Dalam Pendidikan,” Jurnal Widyatama Vol. 19 No (2010).

${ }^{20}$ Sholihat, "Kompetensi Pengetahuan 'Metode Pembelajaran' Sebagai Kesiapan Program Pengalaman Lapangan (PPL) Mahasiswa Prodi Pendidikan Tata Boga."
} 
bahasan tertentu. ${ }^{21}$ Seseorang yang memiliki tingkatan pengetahuan metakognitif berarti mampu berpikir tentang suatu permasalahan, hubungan teori, serta mampu berpikir tentang apa yang sedang dipikirkannya. Hasil penelitian ini menunjukkan bahwa mahasiswa yang memiliki tingkatan pengetahuan metakognitif ada sebanyak $12 \%$. Mahasiswa yang memiliki tingkatan pengetahuan ini mampu menjelaskan dengan baik tahap demi tahap tentang hubungan hukum II Newton dengan energi. Hubungan antara hukum newton II dan transfer serta transformasi energi dijelaskan sampai dengan penurunan rumus keduanya.

Berikut contoh jawaban mahasiswa yang dapat dikategorikan memiliki tingkatan pengetahuan metakognitif :

"Hukum II Newton yaitu membahas tentang percepatan benda yang besarnya sebanding dengan resultan gaya yang bekerja pada benda dan yang berbanding terbalik dengan massa benda tersebut. Persamaan hukum II Newton yaitu $\sum F=m$.a. Setiap benda yang memiliki percepatan maka tentu benda tersebut memiliki energi. Energi mampu berpindah dan mampu berubah bentuk. Energi dapat berpindah sehingga disebut transfer energi, kemudian energi juga mampu berubah bentuk maka disebut transformasi energi. Contoh transfer energi yaitu jika kita menyetrika baju maka ada transfer energi dari setrika ke baju, kemudian di sini akan terjadi transformasi energi juga yaitu dari energi listrik menjadi energi panas. Hubungan antara hukum II Newton dengan energi yaitu :

$$
\begin{aligned}
& E p=m \cdot g \cdot h \rightarrow m=\frac{\sum F}{a} \\
& E p=\frac{\sum F}{a} \cdot g \cdot h \\
& E p=\frac{\sum F}{a} \cdot g \cdot\left(v_{0} \cdot t \pm \frac{1}{2} g t^{2}\right) \\
& E p=\frac{\sum F}{a} g \cdot\left(0 \pm \frac{1}{2} g t^{2}\right) \\
& E p=\frac{\sum F}{a} g \cdot 0 \pm \frac{\sum F}{a} \cdot g \cdot \frac{1}{2} g \cdot t^{2} \\
& E p=0 \pm \frac{1}{2} m \cdot g^{2} \cdot t^{2} \rightarrow v_{t}=v_{0} \pm g \cdot t, v_{0}=0
\end{aligned}
$$

sehingga $g . t=v$

$E p=\frac{1}{2} m \cdot v^{2}$

\footnotetext{
${ }^{21}$ Khoerunisa, "Meningkatkan Hasil Belajar Siswa Pada Pelajaran IPA Materi Siklus Air Dengan Menerapkan
} Metode Pembelajaran Eksperimen." 
Berdasarkan persamaan di atas maka hukum Newton berkaitan dengan transfer dan transformasi energi. Buktinya energi potensial (Ep $=m . g . h)$ mampu bertansformasi menjadi energi kinetik $E k=\frac{1}{2} \cdot m \cdot v^{2}$. Begitu pula sebaliknya"

Berdasarkan hasil penelitian ini beberapa mahasiswa telah mampu memanfaatkan kemampuan berpikirnya sehingga mencapai tingkat pengetahuan metakognitif. Tingkatan metakognitif merupakan tingkatan pengetahuan yang paling tinggi dan paling komplek. Mahasiswa yang memiliki tingkat pengetahuan metakognitif ini sangat menyadari tahapan demi tahapan yang sedang dikerjakannya, mahasiswa juga sadar jika mengalami suatu kesulitan atau kesalahan dan akan langsung berusaha memperbaikinya. Sesuai dengan yang ada pada teori bahwa seseorang yang memiliki tingkatan pengetahuan metakognitif akan sadar dengan kelebihan dan keterbatasannya dalam belajar. Artinya saat seseorang mengetahui kesalahannya, mereka sadar untuk mengakui bahwa mereka salah, dan berusaha untuk memperbaikinya. ${ }^{22}$

\section{Pemahaman Konsep}

Pemahaman konsep mahasiswa dapat dilihat dan diamati dari hasil tes yang telah dilakukan. Nilai rata-rata hasil tes mahasiswa tentang soal mekanika yaitu 79. Nilai ini jika dikonversikan sudah masuk kategori B+. Sehingga pemahaman konsep mahasiswa secara rata-rata baik. Meskipun masih banyak mahasiswa yang mendapat nilai di bawah 60 atau dibawah kategori C-. Mahasiswa dikatakan memahami suatu konsep adalah apabila mahasiswa tersebut mampu menjelaskan suatu konsep dengan baik menggunakan bahasanya sendiri. Apabila menghadapi soal hitungan, maka mahasiswa yang paham akan suatu konsep maka pasti mahasiswa tersebut menyelesaikan soal tersebut dengan runtut dan sistematis dan sesuai dengan konsep yang dimaksud.

Beberapa mahasiswa masih kesulitan dalam memahami hubungan antara konsep satu dengan konsep yang lain. Mereka cenderung hanya memahaminya secara terpisah. Mahasiswa menyampaikan bahwa sulit untuk mencari hubungan suatu konsep apalagi kalau sudah bertemu dengan persamaan. Ini menujukkan indikasi bahwa mereka tidak paham. Bagi mahasiswa yang paham maka untuk mencari suatu hubungan itu dapat dilihat dari definisi konsep, persamaan, contoh dsb. Misalnya hubungan antara konsep momentum konsep impuls serta hukum Newton. Sebanyak 42 mahasiswa yang belum mampu mengkaitkan antara konsep impuls, momentum dan Hukum II Newton. Beberapa di antaranya sudah mampu menjabarkan satu persatu namun belum dapat mengkaitkannya. Sehingga sangat dibutuhkan ketelatenan dalam menyampaikan materi mekanika ini pada saat pembelajaran. Kadang karena dianggap pada fisika dasar telah dibahas maka penyampaian materi ketika mekanika banyak yang langsung materi baru, ternyata hal ini sangat membingungkan bagi mahasiswa yang pemahaman konsep fisika dasarnya masih rendah.

${ }^{22}$ Srini M Iskandar, "Pendekatan Keterampilan Metakognitif Dalam Pembelajaran Sains Di Kelas," ERUDIO Vol. 2 No. (2014). 


\section{Hubungan Dimensi Pengetahuan dengan Pemahaman Konsep Mahasiswa}

Berdasarkan hasil penelitian dapat dilihat bahwa dimensi pengetahuan dengan pemahaman konsep sangatlah berhubungan. Semakin tinggi tingkat pengetahuan mahasiswa maka kemampuan memahami konsepnya semakin baik. Pada hasil penelitian ini dari hasil tes yang dilakukan, mahasiswa yang masuk kategori memiliki tingkatan pengetahuan prosedural dan metakognitif maka nilai hasil tes nya berada di kisaran angka 80 sampai 96. Nilai ini ada di rentang nilai A- sampai A+. Kemudian mahasiswa yang masuk kategori memiliki tingkatan pengetahuan faktual mendapatkan nilai antara 40 sampai 63. Kemudian mahasiswa yang masuk kategori memiliki tingkatan pengetahuan konseptual memiliki nilai antara 64 sampai 79. Hasil itu cukup menunjukkan bahwa antara dimensi pengetahuan FKPM (Faktual Konseptual Prosedural Metakognitif) dan pemahaman konsep mahasiswa saling berhubungan.

\section{PENUTUP}

\section{Simpulan}

Berdasarkan tujuan, pertanyaan penelitian, hasil penelitian dan pembahasan, maka dapat diambil kesimpulan sebagai berikut:

Dimensi Pengetahuan Mahasiswa IPA dalam mempelajari Mekanika sudah cukup baik. Berdasarkan penelitian yang telah dilakukan ada sebanyak 48\% mahasiswa memiliki dimensi pengetahuan tingkat prosedural sehingga mahasiswa sudah dapat melakukan langkah-langkah tertentu ketika menghadapi suatu fakta atau ketika menemui suatu konsep. Mahasiswa telah mampu mengembangkan konsep dan fakta pada materi yang lain yang didalamnya juga membahas konsep dan fakta tersebut. Selain itu mahasiswa yang memiliki dimensi pengetahuan tingkat metakognitif juga sudah ada yaitu sebesar $12 \%$ ini sudah cukup bagus jika mengingat bahwa mata kuliah mekanika dasar termasuk mata kuliah keahlian yang tergolong sulit. Mahasiswa telah mampu memahami apa yang sedang dipikirkannya ketika dihadapkan pada suatu permasalahan dan pertanyaan.

Pemahaman Konsep Mahasiswa IPA pada Pembelajaran Mekanika juga tergolong cukup baik. Hal ini karena berdasarkan hasil tes essay yang telah dilakukan pada 82 mahasiswa nilai rata-rata yang dihasilkan adalah 79. Ini jika dikonversikan maka masuk kategori B+. Tingkat pemahaman konsep mahasiswa yang berada pada kategori rendah (dibawah B-) atau dibawah 60 ada sebanyak 22 mahasiswa. Secara umum maka tingkat pemahaman konsep mahasiswa cukup baik.

Dimensi Pengetahuan serta Pemahaman Konsep Mahasiswa IPA saling berhubungan dan tentu keduanya menunjang keberhasilan Pembelajaran IPA. Semakin tinggi tingkatan pengetahuan mahasiswa maka semakin baik pula pemahaman konsepnya. Berdasarkan hasil jawaban mahasiswa juga terlihat bahwa ketika mahasiswa memahami suatu konsep maka mahasiswa tersebut mampu menjelaskan dan menjawab dengan bahasanya sendiri hal inilah yang membuat tingkatan pengetahuannya semakin baik. Jadi tidak hanya terpaku pada bahasa yang ada di buku 
namun mampu mengembangkan konsep fakta dan permasalahan yang ada kedalam pembahasan yang lebih luas dengan bahasanya sendiri. Begitu pula jika mahasiswa yang mimiliki tingkatan pengetahuan yang tinggi akan lebih mudah menyelesaikan suatu permasalahan sehingga mampu menjawab soal dengan baik yang akhirnya berimbas pada nilai hasil tes pemahaman konsepnya bagus.

Berdasarkan hasil penelitian yang dilakukan menunjukkan bahwa dimensi pengetahuan berkaitan dengan tingkat kemampuan seseorang memahami suatu konsep sehingga ini juga akan berpengaruh terhadap prestasi akademiknya. Jika pemahaman seseorang atas segala sesuatu itu bagus maka jelas kemampuan menyelesaikan masalahnya juga bagus. Sehingga semakin memungkinkan untuk menjadi orang yang berprestasi. Begitu pula pada hasil penelitian terdahulu yang menunjukkan bahwa tingkatan pengetahuan juga berhubungan dengan sikap, maka sangat penting sekali mengetahui dimensi pengetahuan seseorang lalu kemudian berupaya semakin meningkatkan dimensi pengetahuannya apabila masih di tingkat faktual.

\section{Saran}

Sangatlah penting bagi semua pihak untuk mengetahui sejauh mana tingkatan pengetahuannya dan senantiasa mengasah pengetahuannya karena dimensi pengetahuan FKPM sangat berkaitan dengan keberhasilan belajar seseorang.

\section{E. DAFTAR PUSTAKA}

Iskandar, Srini M. "Pendekatan Keterampilan Metakognitif Dalam Pembelajaran Sains Di Kelas.” ERUDIO Vol. 2, No. 2, no. ISSN: 2302-9021 (Desember 2014).

Juanengsih, Nengsih. "Juanengsih, Nengsih, Dkk. 2017. Pengaruh Model Pembelajaran Berbasis Proyek Terhadap Pengetahuan Prosedural Siswa Pada Konsep Eubacteria." BIOEDUKASI Volume 10, Nomor 2 Halaman 23 - 28. 2017 (2017).

Khoerunisa, Eneng. 2013. Meningkatkan Hasil Belajar Siswa Pada Pelajaran IPA Materi Siklus Air Dengan Menerapkan Metode Pembelajaran Eksperimen.

Mundilarto. 2012. Penilaian Hasil Belajar Fisika.

Rukmijati, Lia Yuliati. 2001.Upaya Meningkatkan Pemahaman Konsep Fisika Dengan Menggunakan Pendekatan Kontruktivis Berbantuan Alat Peraga Fisika Pada Siswa Kelas II SMUN 8 Malang.Malang: Lembaga Penelitian Universitas Negeri Malang." Malang : Lembaga Penelitian Universitas Negeri Malang.

Sholihat, Nisa dkk. 2018. Kompetensi Pengetahuan 'Metode Pembelajaran' Sebagai Kesiapan Program Pengalaman Lapangan (PPL) Mahasiswa Prodi Pendidikan Tata Boga." Media Pendidikan Gizi Dan Kuliner Vol.7, No.1.

Suastra, I. W. "Belajar Dan Pembelajaran Sains. Buku Ajar. Jurusan Pendidikan Fisika Universitas Pendidikan Ganesha.," n.d.

Sutriningsih, Naning. 2014. "The Profile Of Teacher Questions On Mathematics Lessons in IX Class Students With Visual Impairment SMPLB YKAB Surakarta. Proceeding 
of International Conference On Research, Implementation And Education of Mathematics And Sciences 2014." Yogyakarta State University.

Widodo, A. 2007. Konstruktivisme Dan Pembelajaran Sains. 200713 (n.d.): 91-105.

Wulandari, Dewi. 2006. Pembelajaran Di Luar Kelas Dengan Strategi Relating, Experiencing, Applying, Cooperating Dan Transferring Pada Mata Pelajaran SAINS Pokok Materi "Pengelolaan Lingkungan Untuk Mengatasi Pencemaran Dan Kerusakan Lingkungan" Untuk Meningkatkan Motivasi Dan Prestasi Belajar Siswa Kelas VII SMP Negeri 4 Malang. Malang: Universitas Negeri Malang." Malang: Universitas Negeri Malang. 